\title{
The Role of Communication Media in Improving Students Achievement at Faculty of Da'wah and Communication, IAI Al-Aziziyah Samalanga Bireuen Aceh
}

\author{
$\underline{\text { Saiful Bahri }}$ \\ Institut Agama Islam (IAI) Al-Aziziyah Samalanga Bireun Aceh, Indonesia \\ Email: tgkdrsaiful@gmail.com
}

\begin{abstract}
:
The focus of this study is the role of communication media in improving students achievement at Faculty of Da'wa and Communication, Al-Aziziyah Samalanga. To answer the focus of the study thoroughly and in depth, in this study used a descriptive qualitative research method that is useful to provide facts and data about the communication media of students at Faculty of Da'wah and Communication, IAI Al-Aziziyah. The data obtained were analyzed using the theory of usage and satisfaction in order to obtain several activities when communicating. From the results of the study it was found that: (1) communication media used by students of Da'wah and communication Faculty, IAI Al-Aziziyah namely books, newspapers, magazines, television, BBM, Line, Whatsapp, Facebook, Youtube and kompas.com (2) the way how to use media student communication of Da'wah and Communication Faculty, IAI Al-Aziziyah namely; join the Whatsapp, BBM, Line group with the aim of exchanging information between friends, faculty, or even between campuses, watching the training videos related to lectures, following a kind of toefl school on Facebook. The role of the communication media in improving the achievements of students of Faculty of Da'wah and Communication, AlAziziyah Samalanga is to make it easier for them to look for references because wherever and whenever they can access them. So as to shorten and save time and place.
\end{abstract}

\section{Keywords:}

communication media; achievement; student

\section{Introduction}

As a social creature, human always wants to connect with other humans, he always wants to know the surrounding environment, even wants to know what is happening in him. With curiosity this forces humans to communicate. Since infancy, humans as homo sociologicus (sociological creatures), that is, humans who live together with other humans, live side by side and in society, since getting out of bed and sleeping again, naturally always involved in the communication process. The occurrence of communication is evidence of the consequences and existence of social interactions or social relations in society. In short, everything expressed by a person in conducting communication is a separate message. That is why where there is life, there is communication.

Communication can no longer be separated from life. Where there are humans there will also be established a communication. Communication is a process of delivering a message to another person or party. The communication process will always occur as long as someone's life process is still ongoing. With communication it will further strengthen relationships between individuals and relationships between groups so that there will be no more seeds of hostility in the process of life. 


\section{Britain International of Humanities and Social Sciences (BIoHS) Journal \\ ISSN: 2685-3868(Online), 2685-1989(Print) \\ Vol. 2, No. 2, June 2020, Page: 503-512}

According to Effendy the term communication or in English communicuttion comes from the Latin word communikatio, and comes from the word communis which means the same. Same here means the same meaning. So, the communication intended by Effendy is a communication that is based on the same meaning of what is being said.

Lasswell revealed a communication paradigm consisting of five elements, namely, (1) communicator; (2) messages; (3) media; (4) communicant, and (5) effect. So what is meant in Lasswell's paradigm is that communication is the process of delivering a message by the communicator to the communicant through the media that has a certain effect. In this case the media is one important aspect in carrying out a process of communication with other parties.

The process is essentially the process of delivering thoughts or feelings by someone (communicator) to other people or interlocutors (communicant). The mind intended is a delivery of ideas, opinions, pendpat or disclosure of a feeling. According to Effeny in a communication process consists of two stages namely, (1) the primary communication process is a communication process that makes the symbol as a communication medium. The symbols meant are language, color, sign, picture, etc. and (2) the secondary communication process is the process of communication that someone conveys to others through a tool, but still makes the symbol as the main media. The secondary communication process occurs due to an obstructing distance between two parties, so we need a tool to smooth the communication fabric.

In this case the communication media certainly has a contribution in the occurrence of a communication. Not only that with the existence of a communication medium, the relationship of one person with another person will be even tighter. The development of technology also affects the existence of communication media. Distance is no longer an obstacle in communication. Of course, with the development of technology, humans are increasingly benefited by many things ranging from unlimited space and time and facilitate human activity. The development of communication media in the modern direction has both positive and negative impacts. These impacts do not only attack a number of people.

Academics, such as the students of the Da'wah and Communication Faculty of IAI AlAziziyah Samalanga Bireuen, also felt the impact of the development of increasingly advanced and sophisticated communication media. Social media has a great influence on human life. Not only makes it easier for humans to communicate but also affects the world of education, especially on learning achievement. A student of the Da'wah and Communication Faculty of IAI Al-Aziziyah Samalanga Bireuen who also felt the positive impact of communication media in their learning achievement. When they does not have a smartphone their GPA is around 2.7, because they takes a long time to do the work so it exceeds the deadline for collection. However, when they already has a smartphone they can complete the task quickly so that their GPA rises around 2.9.

This communication media has a positive and negative impact on the learning activities of the students of Da'wah and Communication Faculty Al-Aziziyah Samalanga Bireuen, the negative impact is that there can be many abuses such as fraud and can also make someone forget time. While the positive impact is to make thinking more advanced, making it easier for someone to do activities including in searching for data and also saves more time spent. If they can use the media properly and correctly, they will get useful things as well as the students of the Dawah and Communication Faculty of Al-Aziziyah Samalanga Bireuen 
who have succeeded in increasing their achievements. Of course it is very interesting to conduct a study that communication media has positive and negative impacts in improving academic achievement, especially students of the Da'wah and Communication Faculty of AlAziziyah Samalanga Bireuen.

\section{Review of Literatures}

\subsection{Overview of Communication Media}

Communication is the basis of all human interactions. Because without communication, interaction between humans, both individuals, groups, and organizations is not possible. Personal communication is communication around a person, both in its function as a communicator and communicant. Individuals who can communicate effectively with anyone or anywhere, will bring personal growth. Instead the individual cannot communicate effectively, he will experience barriers to personality growth (Davis, 1940; Wasserman, 1924).

Thus, for interpersonal communication to run smoothly and bring results that are applied, both the sender and recipient of the message need to have the necessary interpersonal skills and communication. Interpersonal communication competence is the level where our behavior in interpersonal communication is appropriate and appropriate to the situation and helps us achieve the goals of interpersonal communication that we do with others. In other words, communication media are all means used to produce, reproduce, distribute or disseminate and convey information.

Communication media plays an important role in people's lives. The process of sending information in modern times is very sophisticated. Telecommunications technology is most sought after to deliver or send information or news because telecommunications technology is increasingly developing, faster, more precise, accurate, easy, inexpensive, effective and efficient. Sharing information between continents and countries in any part of the world is easier.

\subsection{Overview of Student Communication}

Students are people who study in college, whether in universities, institutes or high schools. Those who are registered as students in tertiary institutions can be called students. But basically the meaning of students is not that narrow. Registered as a student in a Higher Education is only an administrative requirement to be a student, but being a student contains a broader understanding than just the administrative problem itself. Carrying a student degree is both a pride and a challenge. Imagine, the expectations and responsibilities held by students are so great. Students' understanding cannot be interpreted word for word, Student is an agent of change. Being a person who can provide solutions to problems faced by a nation society in various parts of the world.

The young generation in this case is students, within the structure of Indonesian education, students occupy the highest level of education unit among others. One of the functions of students is that they are "agents of change" because students have a very important role in determining the fate of a nation.

As a student of various kinds of furniture, there are several kinds of labels attached to students, for example:

a. Direct Of Change, students can make changes directly because of their many human resources

b. Agent Of Change, a change agent student, means human resources to make changes 
c. Iron Stock, the human resources of that student will never run out.

d. Moral Force, students are a group of people who have good morals.

e. Social Control, students are controllers of social life, for example controlling social life done by the community.

\subsection{Research Supporting Theory}

Based on the data above the relevant theory to be used is the Used and Gratification Theory (theory of use and satisfaction). The theory of use and satisfaction is mentioned as one of the most popular theories in the study of mass communication. This theory proposes the idea that individual differences cause audiences to seek, use and respond to media content differently due to various social and psychological factors that differ between individual hearings.

S. Finn (1992) states that a person's motives for using media can be grouped into two categories, namely proactive and passive. Examples of proactive media use are using certain social media to get entertainment, or browsing using the internet to get information to help complete college assignments or the like. In other words, media users are actively seeking information from the media based on their wants, needs, and motives.

The assessment of media content is determined by the audience. According to this theory, media content can only be judged by the audience itself. Social media or other communication media that are considered unattractive can be attractive to certain audiences because they feel satisfied by using them. According to J.D. Rayburn and Philip Palmgreen (1984), someone who reads a particular newspaper does not mean he is satisfied with the newspaper he reads because maybe only that newspaper is available. He will immediately turn to another newspaper if he gets a chance to get another newspaper.

\section{Research Methods}

To answer the focus of the research thoroughly and in depth, in this study used a descriptive qualitative research method that is useful to provide facts and data about the communication media of students at Da'wah and Communication Faculty of IAI Al-Aziziyah. The data obtained were analyzed using the theory of usage and satisfaction in order to obtain several activities when communicating

\section{Discussion}

\subsection{The Role of Communication Media in Improving Students Achievement at Faculty of Da'wah and Communication, IAI Al-Aziziyah Samalanga Bireuen Aceh}

The role of communication media in modern times like today certainly cannot be denied is very influential, because communication media in this modern era are very helpful in terms of time and place will be more practical and efficient. As explained by one of the students of the Faculty of Da'wah and Communication of the Institute of Islamic Religion (IAI) Al-Aziziyah Samalanga Bireuen Aceh Study Program Bimbinga and Islamic Counseling, as follows:

"Yes, if I think it's important, the question is that it supports the learning process like looking for literature for the paper, so it can be an alternative, because if the books in the library are lacking or not enough money to buy books and borrow, no one has the right to search on the Internet. But usually I am picky to look for literature especially like e-books, but if blogspot and woadprest like that if you can avoid it sis. Yes, it is important to support such applications to provide information like that ... hehe 
... Not really, not so dependent because there can indeed be literature from books in the library, then most of the things we take from the internet like blogspot are not strong enough for us to make it reference but there is something we can make a reference even from the internet like an e-book sis."

From the results of the presentation, there are several roles of communication media used daily. Furthermore, the results of interviews of students who are still with the Islamic Community Study Program of FDK IAI Al-Aziziyah:

"Yes, because now all information can be more effective in overcoming space and time limitations. We can discuss through communication media wherever and whenever. It is undeniable that in this day and age who do anything certainly can not be separated with this one media, if you say it depends do not really but it is the circumstances that force it. That is what I mean is yes to always use communication media but do not depend too."

After the explanation from the two students from Islamic Community Development Study Program, FDK IAI Al-Aziziyah, the next presentation was from the Islamic Communication and Broadcasting student:

"I think it's important too, because in today's era of fast paced internet we also have to keep up with the times, sometimes people will miss information too if they don't use internet-based communication media or social media. As info activities so if we do not join certain groups us also will not know. No, it does not depend, but rather just as a support, to function as needed, which plays a large role if the intended academic achievement is a book, because the source is more secure."

As for students who gave explanations that:

"It's very important because we need information about books or references to support my achievements, I will use internet media with laptop. In addition, when communicating or sharing with friends, I also need a smartphone to convey my message even without face to face. It does not always depend on the media because a media certainly has its negatives and that will make us dependent so it makes us lazy and takes things lightly. "

Another with the presentation of students with the same study program:

"Yes, because it can facilitate access, save time and space. Broad reach and can get a lot of information. No, because the media is a tool that makes it easy for us. So how can you achieve it from yourself? What is his enthusiasm for developing soft skills?"

Different is the case with the results of interviews with different study programs, namely from the Islamic Community Study Program FDK IAI Al-Aziziyah:

"Very important role, because from the communication media that I get information such as competitions, job vacancies, news today and most importantly add a friendship channel. It does not depend because the communication media is only a tool for me."

After explaining one of the students of the Islamic Community Development Community FDK IAI Al-Aziziyah about the role of the communication media, then from the students of Islamic Communication and Broadcasting, as follows:

"Yes, it is clear, bro, when the source of books or books in the library does not exist, where do we run to? Of course, to the communication media such as the internet, 
YouTube and others. But we must be able to choose which sources can be trusted and which sources can not be trusted, and when we only take the origin of the plot (take) it is the same we are not trusted and one of the most important. When we take it from the internet we have to include from which links we take it so that we are not exactly a copycat or copy paste. If it is said that it depends, it really does not depend, it depends on the beginning and the individual. For example, if the internet is used as a means of supporting us the most, I don't think it is because the one that supports it, in my opinion, is a book because books are a trusted and accountable source. If it is still not new enough from the internet so that at the time of presentation it can cover a lot of the material. I explain again that if this kind depends on each individual."

It is different from the presentations of the next students, even though they are a Study Program:

"For its important role, it's 50-50, because we have to update the latest news through this communication media, usually from Whatsapp from the group, there is also important information. It's not that much depends on the problem because I am more often Whatsapp and BBM only for information like organizations. I also just open the news if I have the chance, but I want to, but I target to open the compass once a day, opening the compass to update the latest news."

Furthermore, it is still from the same study program with a different presentation, namely:

"Communication media become an important role not only in increasing achievement, but communication media are also very important in our daily lives. I am sure there will be no one who says they don't need communication media, aren't there many kinds of communication media? Such as telephone, letters, newspapers, books, internet and so forth. Even people who live in the interior I think would argue that communication media is very important. Although they cannot use it due to signal factors and so on. If it is said to be very helpful, then I answer not really, because it is often the lecturer who is more able to understand me about a subject in the course than I browse."

After the explanation from several Islamic Communication and Broadcasting students. Next is the presentation from one of the Islamic Community Development students:

"Very, very important, because here I am a student, we continue to live in a modern era like this if communication media is not important and not numbered in the community, when can society develop, right? Now he thinks there. Because of that, for me, communication media is very important, especially visual media, and the printing of the masses is very important to play a role in the world of society or at least in the world of intellectuals. So it is very supportive if the communication media continues to be developed, indeed there is a positive value in the environment either for students or for others even not only people in the field of education who must learn this, general people or ordinary people need to even the cloud usually learn it instead from print media first, but they learn from visual media first, he sees from television, sees from a story and so on. Usually it's ordinary people but if people are educated they usually look for books and then look for the visuals, that's for me. Yes, really, if I am very dependent because communication media that enhance our achievements, the existence of a smart person because of the communication media. So smart people are because of communication, because thanks to the communication media people can gain insight, increase experience, increase knowledge because of the communication media. For me, if you ask about this question about the dependence of this communication media, it is 
indeed very useful, because all humans are very dependent on this communication media. People will not be able to develop and people will be said to miss that communication when they cannot balance the communication media in their daily lives. That's why sometimes people are quiet in our environment, because of what? He does not balance, yes we need to learn this knowledge, he is not direct for me to have to look for books, that's why sometimes people when we invite weak discussion, miss communication in forums and that's the importance of communication media and achievement will increase by itself when the communication media goes like it was developed."

Moving on from the above research data exposure, then in the theory of use and gratification (theory of use and satisfaction), according to Blumer there is what is called Intentionality, which is motivation before people determine consumption of media content. Motivating before people determine the consumption of media content is one of the roles of communication media in improving the student's achievements of the Da'wah and Communication Faculty, Al-Aziziyah Samalanga. So the communication media here according to the theory of use and gratification (theory of use and satisfaction) before students determine what media content to consume media has motivated these students to determine the consumption of media content to be used.

\subsection{Author's Analysis}

In qualitative research, data is a useful step in analyzing data obtained from several informants who have been selected by researchers during this research. It is also useful in explaining and ensuring the truth of the research. As for the research that has been done, the researcher obtained several interview comments from each informant and the findings are categorized in several categories, viz.

The media has a very important role for information providers to support the achievements and insights of students. In modern times technology is becoming increasingly sophisticated. And that also has an impact on the media used by students in improving their achievements in academic and non-academic fields. In the past, students could only gain knowledge by starting to read books either buying needed books or simply borrowing from the campus library and borrowing from friends who owned the book or listening to lecturers while explaining while in class but in modern times this knowledge can be obtained directly from all communication media. The media used by the students of the Da'wah and Communication Faculty Al-Aziziyah Samalanga are:

\section{a. Print Media}

The print media used by students of the Da'wah and Communication Faculty of IAI Al-Aziziyah Samalanga are books and newspapers. Open is certainly not going to be separated from the students because the books are accurate and can be accounted for. As when going to work on assignments in the form of papers or presentations from the lecturers certainly these students need references as their support when compiling the data of the paper and also can be made the basis of their accountability for making the paper. Likewise when the presentation with them has the basis of the required book, surely this student will be more confident when answering questions and refutations both from fellow students and from lecturers supporting the course.

Besides this book is also useful to add insight into the student if the student wants to have knowledge or insight from outside the department. By not only reading books with a theme that is appropriate for the majors, such as students of the Da'wah and Communication 
Faculty of Islamic Community Development Study Program who want to increase their knowledge and insight in the field of photo editing or making advertisements they can read books from the Islamic Communication and Broadcasting Study Program.

\section{b. Online Media}

This online media is in the form of internet and social media. The internet is short for interconnected networking. In general, the internet is a network that connects millions of computers throughout the world. There are two kinds of networks available, the first is LAN, and this network has an exchange of information between users in a relatively small area. The second is WAN, this network allows communication between fellow users but in a larger area and covers all regions of the world. Second is the Internet, such as Google, YouTube and opera, which are often used by students of the Da'wah and Communication Faculty AlAziziyah Samalanga to conduct searches or commonly referred to as browsing aimed at finding information, insights or even looking for references in doing lecture assignments.

If these students have not found references in the books they read they begin to look for them on the internet, even though the internet is less convincing and cannot be accounted for properly, but these students still do it. But they are more sorting through taking data on the internet, such as avoiding those from Wordprest and Blogspot. They prefer those from ebooks and e-journals. Because according to them e-books and e-journals can be more accountable if they are made as references. While youtube is usually used to view videos that aim to learn or to learn from the video. Like how to be a good MC how to do it and also other tutorials.

While social media used by students of the Da'wah and Communication Faculty AlAziziyah Samalanga are like Whatsapp, BBM, Line, and Facebook. They usually create a group between the true campus that aims to exchange information and insights and can also share the existing problems. In the group they students can discuss and find solutions together even though sometimes they don't know each other. They can also attend like a toefl school that is on Facebook, which meets once a week on Facebook by sharing videos on how to read English correctly. And there are also groups that discuss books and free journal addresses without paying to read them, sometimes even those discussed in the group that turn out to be blinded for presentation material in class.

\section{c. Electronic Media}

This electronic media, the students of the Da'wah and Communication Faculty of IAI Al-Aziziyah Samalanga also used it to improve their achievements, although compared to print media and online media, this electronic media played only a small role. Like television, what they usually do is to watch the updated news so they don't miss the information. Or you can also watch a movie with a motivational theme. However, like mobile phones and leptops, this is also important as a tool to access the internet, if there are no cellphones or leptops, they will not be able to access the internet, so it can be called electronic media and online media have continuity with each other.

From the results of research conducted by researchers produced several researchers' findings. There are two kinds of research findings here. That is:

a. The increasingly sophisticated communication media now make it easier for students of the Da'wah and Communication Faculty Al-Aziziyah Samalanga to obtain knowledge and information. In this first meeting, students of the Dawah and Communication Faculty of IAI Al-Aziziyah Samalanga in improving their achievements could not be separated from the development of increasingly sophisticated communication media. Because with the 
increasingly sophisticated communication media so that they are easier and faster in finding the information they need in lecture activities every day. Even though books are still the main media they use in looking for references, but if they only rely on books, they will certainly lack information because there are still limitations, these limitations are like books needed are not available in the library, and friends also do not have the book and limited money to buy the books needed. Therefore they complement their learning by using the internet. Like using online libraries, Google, Youtube, Facebook, BBM, Whatsapp, Line, and so forth.

b. In these three criteria each criterion has a different use of communication media. In this discovery the differences in the CPI also affect the use of the communication media used. A high GPA of 3.51-4.00 prefers to read a book first, so if there is no book they are looking for it on the internet and social media. Although they recognize that with the sophistication of communication media now everything is easier and more practical. Because communication media such as Whatsapp, Facebook, Youtube really help them in real learning like watching tutorials on Youtube and joining Whatsapp groups. While the average GPA between 3.01-3.50 is not much different from the GPA between 3.51-4.00 because they are just more relaxed in daily learning. Furthermore, the low GPA is 2.503.00 , they prioritize practicality and speed in the process and most of them prefer to read the internet without reading in a book first.

\section{Conclusion}

From the results of the study found that the communication media used by students of the Da'wah and Communication Faculty IAI Al-Aziziyah namely books, newspapers, magazines, television, BBM, Line, Whatsapp, Facebook, Youtube and kompas.com. How to use the communication media for students of the Da'wah and Communication Faculty of IAI Al-Aziziyah namely; join the Whatsapp, BBM, Line group with the aim of exchanging information between friends, faculty, or even between campuses, watching the training videos related to lectures, following a kind of toefl school on Facebook. The role of the communication media in improving the achievements of students of the Da'wah and Communication Faculty Al-Aziziyah Samalanga is to make it easier for them to look for references because wherever and whenever they can access them. So as to shorten and save time and place. Furthermore they can also discuss even without face to face. Starting from this research, some suggestions that can be taken into consideration by the Da'wah and Communication Faculty Al-Aziziyah are that the faculty and study program direct their students to hone communication skills possessed by students.

\section{References}

Associaton, P. The Casual Gaming Market Update, Amerika. 2013.

Baran, Stanley J. Pengantar Komunikasi Massa Jilid 1 Edisi 5. Jakarta: Penerbit Erlangga. 2012. Danim, Sudarwan. Transformasi Sumber Daya Manusia.. Jakarta: Bumi Aksara. 2007.

E, Katz, Blumler, J. G., \& Gurevitch, M. Winter. Uses and gratifications research. The Public Opinion Quarterly. 2007.

Finn, S. Television Addiction? An Evaluation of Four Competing Media-Use Models, Journalism Quarterly 69. 2007.

Hardjana, Agus M. Komunikasi Intrapersonal \& Interpersonal. Yogyakarta: Penerbit Kanisius. 2013.

Hasbullah, Muntasir, Saiful Bahri, Riska Zahara, Zulfia, Messages Communication in the AlQur'an (Study of Messages in the Al-Qur'an for Believers), Budapest International Research and Critics Institute-Journal (BIRCI-Journal): Volume 2 No. 4, November 
2019. (http://www.bircu-journal.com/index.php/birci/article/view/569)

Katz, E, J.G. Blumler \& M. Gurevitch. 2007. Utilization of Mass Communication by the Individual, dalam Richard West dan Lynn H. Turner, Introducing Communication Theory, McGraw Hill. 2013.

Kriyantono, Rahmat. Teknik Praktis Riset Komunikasi. Jakarta: Kencana Prenada Media Group. 2013.

Liliweri, Alo. Komunikasi Serba Ada Serba Makna. Jakarta: Prenada Media Group. 2011.

Littlejohn, Stephen Wdan Karen A. Foss. Theories of Human Communication, Eighth Edition, Thomson Wadsworth. 2011.

Margono, S. Metode Penelitian Pendidikan.cet II. Jakarta:Rineka Cipta. 2011.

McQuail, D, J.G. Blumler \& J. Brown. The Television Audience: A Resived Perspective dalam D. McQuail (Ed.), Sociology of Mass Communication, Penguin Books. 2011.

Muntasir, Saiful Bahri, Yusfriadi, Muttaqien, Ahmad Nidal, Fadlon, Human Communication with God through Asmaul Husna (99 Names of Allah) (Study of Asmaul Husna's Understanding in Islamic Theology), Britain International of Humanities and Social Sciences (BioHS) Journal : Volume 1 No. 2, October 2019 (http://biarjournal.com/index.php/biohs/article/view/45)

Moleong, Lexy J. metode penelitian kualitatif . Bandung: Remaja roskadarya. 2011.

Morrisan. Teori Komunikasi Individu Hingga Massa, Kencana. 2011.

Rachmad, Jalaluddin. Psikologi Komunikasi, Bandung: Remaja Rosdakarya, Bandung. 2011.

Rayburn, J.D. \& P.C. Palmgreen. Merging Uses and Gratification and expectancy-value theory, Communication Research. 2011.

Rosul, Juharis , M. ed. Teknologi Informasi dan Komunikasi 2 Quadra. 2011.

Ruslan, Rosady. 2006. Penelitian Public Relation dan Komunikasi. Jakarta: Raja GrafindoPersada. 2011.

Saiful Bahri, Hadiths About Communication Ethics (Study of Hadiths about Responsibility and Maintaining Information Accuracy), Budapest International Research and Critics Institute-Journal (BIRCI-Journal) Volume 1 No. 4, December 2018, http://www.bircu-journal.com/index.php/birci/article/view/118

Sarwono. Perbedaan antara Pemimpin dan Aktivis dalam Gerakan Protes Mahasiswa. Jakarta : Penerbit Bulan Bintang. 2011.

Wirjoyokusumo, Iskandar \& Sonardji Ansori. Metode Penelitian Kualitatif. Surabaya: Unesa University Press. 2011.

Kamus Besar Bahasa Indonesia. Edisi Keempat. Jakarta : Gramedia Pustaka Utama. 2011. 